\title{
Decision Factors for Domestic Tours in Egypt: Analyzing visitor's profile, behavior and holidays' characteristics
}

\author{
Lamiaa Hefny \\ Department of Tourism studies, Faculty of Tourism and Hotels management \\ Pharos University
}

\begin{abstract}
Tourism acts as a vital economic sector, though, revenues generated by domestic tourism in Egypt are far below expected levels. This paper aims to profile the Egyptian pleasure traveler based on travel attitude and behavior. The paper also investigates travel-related characteristics in the Egyptian pleasure travel market. A survey was conducted among the Egyptian pleasure travel market to identify the importance of decision factors for domestic tours and the most important perceived reasons for selecting a domestic holiday. This paper reports on initial findings of a more comprehensive research on the psychographic background of Egyptian travelers. This research explores the different factors affecting domestic tourism in Egypt, also its trends and attributes. Implications required to increase numbers and expenditures of domestic tourists were suggested.
\end{abstract}

Keywords: Domestic tourism, visitor profile, travel-related characteristics, travel behavior

\section{Introduction:}

It is crucial for a tourism manager to research and understand the way in which consumers make decisions and the factors that motivate and encourage tourists to make particular purchases. Also, when analyzing a tourist's consumer behavior must take into consideration: the needs and habits of the consumers, consumer preferences and requirements, and motivational factors. The issue of decision making is more than where or when to travel. Actually it is a complicated decision making process with numerous variables involved in it. The consumption process of tourism holiday choice, or travel decision making, is influenced by a number of factors such as personal characteristics, desires and attitudes as factors that affect the vacation decision making process. Models of consumer behaviour' has been adapted to describe tourism holiday choice process.

When compared with the purchasing of tangible goods, consumer behaviour involved in the purchase of tourism products has the following characteristics: high involvement in the purchase decision and high consumer commitment; high levels of insecurity linked to intangibility; considerable emotional significance; strongly influenced by other people; the decision has long-term consequence; and a high level of information search (Starbrooke \& Horner, 2007). The decision to spend non-refundable money on travel versus purchasing tangible products involves psychological determinants. The most important variables are demographics and lifestyles among others that are prestige, escape, sexual opportunity, education, social interaction, family bonding, relaxation, and self-discovery (Kotler et al. 2006)

However, researchers often see consumers' decision making as a sequential process, which involves several steps from need recognition, information search, evaluation and comparison of products, and then to final purchase decision (Kotler, 1997, Schiffman \& Kanuk, 1997; Solomon, 1996). In the context of tourism, tourists' destination choice is also a sorting out process, which contains a series of steps, including obtaining passive information, initial choice considering situational constraints, evaluation of an evoked set, active information searching and the final destination selection (Um \& Crompton, 1990). This sorting out process could be influenced by a number of various internal (motivations, attitudes, needs, etc.) and external factors (information, price, spare time, etc.) (Woodside \& Lyonski, 1989; Um \& Crompton, 1990; Crompton \& Ankomah, 1993).

The decision-making process involves a number of decisions that tourists have to make. It is not just selecting the destination, but includes decisions about date of travel, travel group members, budget, length of stay in destination, activities, etc. Tay et.al (1996) proposed a model for recreation trip that comprised five interrelated sub-travel decisions, including choice of destination, duration and frequency of trips, travel mode, and trip timing. Other researchers (Jenkins, 1978; Mountinho, 1987) suggested that the trip decision covers an even greater number of sub-decisions, such as: extent and nature of information search, whether or not to take children, length of trip, date/timing of year to travel, mode of transportation, travel budget, activities, accommodation and destinations. Later, researchers looked at the subdecisions in more detail. According to Fesenmaier \& Jeng's (2000), there are three basic levels of decisions: (1) core decisions, which are planned in detail well in advance of the trip including primary destination, date/length of trip, travel party/members, accommodation, travel route, overall travel budget; (2) secondary decisions, which appear to be considered prior to the trip but also considered largely flexiblell to accommodate the possibility of change such as 
secondary destinations, activities; attractions; and (3) en route decisions, which are not considered until the travellers are actually en route such as rest stops on the road, restaurant stops, shopping places, items to purchase, budget for gifts and souvenirs etc.

\section{Decisions factors of holiday choice}

Holiday-related decision-making and methods being employed to analyze these choices are prominent areas of study within the tourism fields, because this type of travel plays such a vital role in the world economy. The literature focusing on holiday destination choice decisions and its relation with three factors: tourist behavior, the tourist profile, holidays' characteristics. Deciding factors in buying a holiday include, besides the traditional criteria of price, service quality, facilities, etc., an increasing concern for the quality of the environment (Swarbrooke, 2009). Therefore, the tourist profile, personal characteristics, including: age, occupation, level of income, living conditions, social category, level of education, residential environment, attitude, system of values, etc., will be reflected in the motivation to travel. At the same time, the features of the destination, including diversity and quality of attractions, distance, price, facilities, quality of service, will define a certain image thereof. Harmonization of the two categories of features, the motivation and the destination image with the expectations of the tourist will result in the latter's option for a certain product, i.e. destination, followed by purchase and consumption - the actual spending of a holiday (figure no. 1). From the perspective of modern tourism, apart from these defining elements of consumer behavior, an increasing role is played by the results, the experience gained at the visited location is appreciated on three levels: personal satisfaction, the needs of the host communities and the quality of the environment (Bowen and Clarke, 2009).

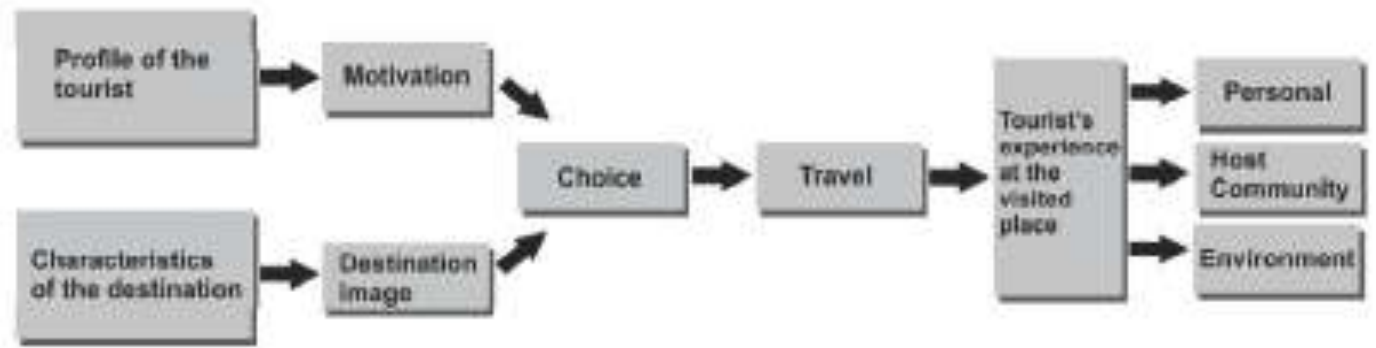

Figure (1) Conceptual scheme of the modern tourist's behavior

Source: Bowen, D., \& Clarke, J., (2009), Contemporary tourist behaviour: Yourself and others as tourists. London, UK: Oxford Brookes.

Holiday destination studies typically focus on three main types of independent variables and their interaction effects: personal characteristics, destination characteristics, and trip characteristics. Personal characteristics include factors such as age, education, household composition, income, and place of residence (Baloglu and McCleary,1999; Bargeman and Poel, 2006; Eugenio-Martin, 2008). Destination characteristics include attributes such as climate, the presence of different kinds of activities, the presence and extent of coastline, quality and range of accommodations, degree of development and destination area size, costs related to food, transport, and accommodations, and exchange rates (Johnson and Ashworth, 1990; Baloglu and McCleary,1999). Trip characteristics include travel distances, costs, travel times, and vacation purpose (Bargeman and Poel, 2006; Eugenio-Martin, 2008). In tourism research, much attention has been paid to understanding the factors contributing to destination choice, intention, and the extent of multi-destination tour. These efforts generally include both supply-side and demand-side factors. Supply-side factors indicate the opportunity to visit distinct destinations based on location-specific attributes, while demand-side factors, such as individual tourist characteristics, reflect tourists' desire to visit more than one destination based on the need to participate in a complete tourist experience (Wu \& Carson, 2008). From the demand side, a large number of studies have examined the determinants of multi-destination tourism, concluding that single- and multi-destination tourists differ in terms of demographic profiles, trip types, motivations and intentions, service quality assessments, and their propensities to participate in cultural activities (McKercher \& Wong, 2004).

Recently, however, researchers have begun looking past these standard factors into more insightful measures of traveler preferences and motivations. This is in response to the fact that tourists are becoming increasingly demanding and selective about their holiday travel, which, in turn, is leading to an increasingly competitive tourism market. Preference data provides details beyond personal characteristics or trip purposes, such as what a traveler looks for on a trip, their motivations for taking a trip, and prior expectations and experiences. These methods attempt to capture the part of a traveler's personality that Beerli et al. describe as the "inherent desires for leisure travel that control where and how often an individual will travel". Researchers and practitioners are incorporating such preferences into their studies on tourism demand in various ways, including by considering stated motivation factors, prior travel experiences, and ranking preference scales (Beerli et al.2007) The most common method to consider traveler preferences is to incorporate stated motivation factors from surveys or interviews into models and comparative studies (Papatheodorou, 2001). These factors highlight what travelers expect to accomplish on their trip or the personal benefits they hope to gain from taking a holiday (Baloglu and McCleary, 1999). Many studies interpret these factors as 
a 'level of appreciation', i.e. how much a traveler appreciates such activities as nature gazing, cultural heritage awareness improvement, shopping and dining, and outdoor recreation (Lehto et al, 2004). Others describe it as a 'level of interest'. Nicolau and Mas used this latter definition in their review of interest in new places and new cultures (Nicolau and Mas, 2005). Motivation factors have also been used to describe how travelers perceive their destinations. Baloglu and McClearly evaluated how various destinations were perceived based on how well they would allow travelers to relax, have excitement, gain knowledge, be social, and attain prestige (Baloglu and McCleary,1999). Research in tourist decision-making process is needed for statistical profiles of tourists: age, gender, stage in a family life cycle, places of residence, occupation, income etc. This data is gathered on various scales: talking about the whole country, region or just some single tourist attraction. Secondly, statistical data on tourist behavior is needed: the popularity of different destinations, preferable time of vacations, frequency and duration of vacations. (Keegan \& Green 2008, 197-198.) Thirdly, the process of making decisions is important, especially concerning vacations, the roles of family and group members in it, conditions and time when the purchasing decisions are made. The next issue to research is perceptions of tourists as regards destinations, types of holidays, means of transport, different services etc.

\section{Visitor Profile}

Nowadays, tourist consumption is characterized by internal differentiation or diversification due to multiple factors. As a result, increasingly greater attention has been paid to tourist typologies, classifications and segmentations in analyses of tourist behavior. The tourism literature is full with typologies that group tourists by common characteristics to better understand and to predict behavior (Cohen, 1972 \& Plog, 1974). Numerous studies developed typologies based on segmentation variables including demographics, psychographics, personal values and lifestyle, benefits sought, behaviors, motivations, experiences and emotional response.

Clearly, the habits of tourists are heavily influenced by their socio-demographic contexts, i.e., education level, age, economic activity, environment and lifestyle, with the largest percentage of tourists who travel being those with a higher level of education and employment positions that include greater responsibilities and salaries.

Socio-demographic and travel behavior variables are generally used in tourism research in order to identify the characteristics of tourists. The socio-demographic variables mostly include age, gender, income, marital status, occupation, education, and nationality. There are also studies that exemplified the conceptualization of tourist profile construct. For instance, Franch, Martini, Inverardi, and Bufa (2006) identified tourists' profile of the Dolimite area of Italy using two dimensions: socio-demographic characteristics and the organization of the holiday. Kozak et al. (2004) also characterized tourist profile as an amalgam of socio-demographic variables, in addition to travel behavior variables. In Chun's study (2009), the tourist profile included demographic features of guests visiting international tourist hotels in Taiwan. Variables measured were age, gender, purpose of trip, occupancy, and education. The study also revealed that different segments of international tourist markets could be identified in terms of demographics and characteristic features of the tourists. Castano, Moreno, and Crego (2007) examined the profile of tourists visiting Spain; and they identified eight types of tourist profile including professional, urban, holiday, holiday-sun-and-beachactive population, holiday-sun-and-beach-active population, holiday-rural, rural-sun-and-beach, and active-rural. Their study conceptualized the tourist profile construct into two dimensions: socio-demographic characteristics and travel patterns.Kattiyapornpong and Miller (2007) posits that age, income and life cycle will have less of an effect on travel preferences and a greater effect on travel intention and travel choice due to the application of the leisure constraints model (Samdahl \& Jekubovich, 1997). Therefore these socio-demographic variables are hypothesized to inhibit or constrain travel rather than to determine preferences. It is expected that age, income and life stage will not impact strongly on travel preference. Mieczkowski (1990) quoted tourist age as one of the most important demographic dimensions which influence holiday demand. Romsa and Blenman (1989) studied the vacation patterns of the elderly Germans using the environmental motivational model. They found that environmental, socioeconomic, and aging effects prevented seniors from joining more fully in the tourist wave. Also, income has been shown to be significantly related to holiday taking behaviour (Mergoupis \& Steuer, 2003). McGehee, Murphy and Uysal (1996) investigated the Australian international pleasure travel market. They found that Australian women and men are motivated differently in their pleasure travel experience.

\section{Visitor behavior}

The theory of planned behaviour (TPB) is an established theoretical model of explaining the relationship between consumers' beliefs, attitudes, intentions, and behaviours (Ajzen, 1991, 2001). TPB has been applied in a variety of studies on social behaviour, including studies on the decisions of students completing high school (Davis, Ajzen, Saunders \& Williams, 2002), consumer choices of transportation mode (Bamberg, Ajzen \& Schmidt, 2003), the influence of negative word-of-mouth on Chinese consumers' intention of choosing restaurants to dine at (Cheng, Lam $\& \mathrm{Hsu}, 2006$ ) and, attitudes toward wine tourism (Sparks, 2007). Similarly, TPB has been applied to assist in explaining consumers' complex travel decision-making process (Lam \& Hsu, 2006). For example, Hsu, Kang and Lam (2006) examined reference groups' influences on Chinese travellers travel intentions, and Lam and Hsu (2006) applied TPB to study intentions of Taiwanese travellers choosing Hong Kong as a travel destination. Lam and Hsu (2006) found that TPB provided a good model fit for potential Taiwanese travellers to Hong Kong. Their research emphasized the importance that factors like social influence and perceived behavioural control play for this group. 


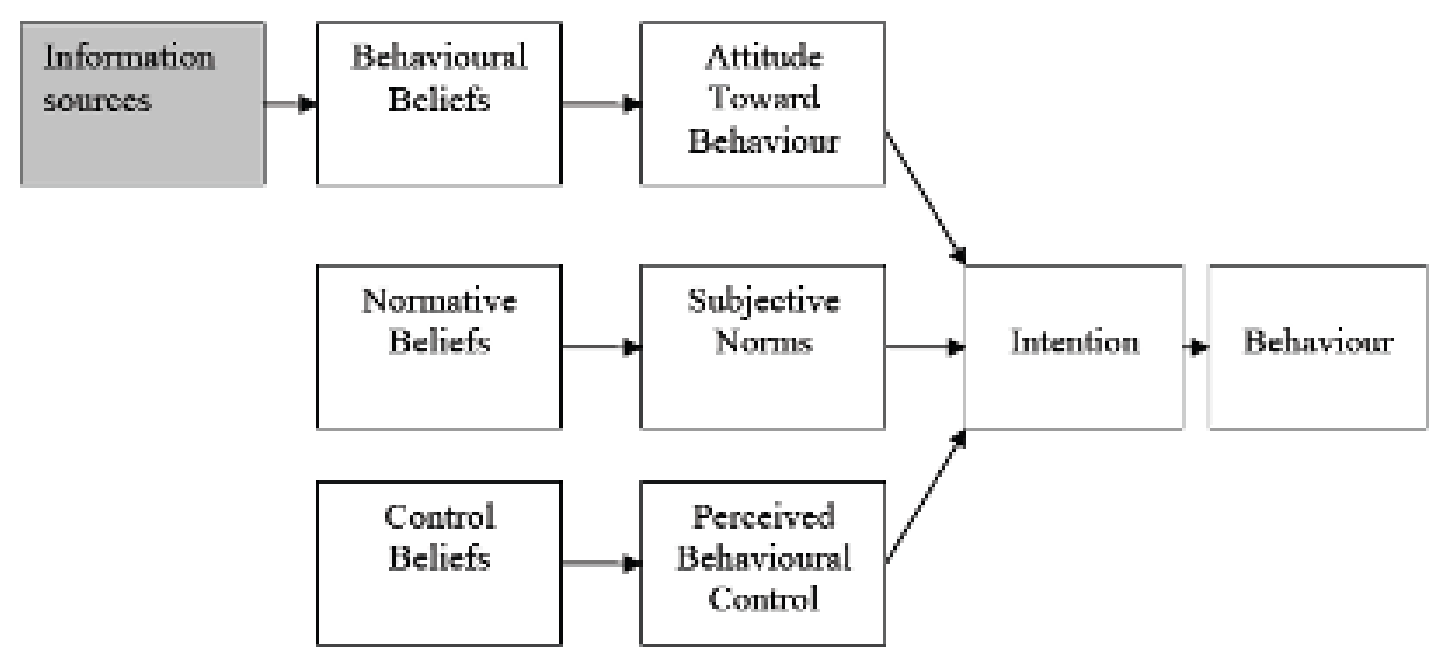

Figure (2) The Theory of Planned Behavior

Source: Ajzen, I. (1991), The Theory of Planned Behavior. Organizational Behavior and Human Decision Processes, 50, 179-211.

Consumer behavior research in tourism has lots of weaknesses, which make it difficult to analyze the data and empirical material. There is lack of research which describes changes in tourist behavior over time and a lot of data is outdated or based on small samples of tourists. Little research is also done about studying the links between preferences of tourists and the products they purchase and on tourist motivations and determinants of their behavior (Swarbooke \& Horner 2007).

Information search behavior Research on tourist behavior has to begin with information search. One of the most influential factors in the purchase of a tourist product (destination) is information about tourist goods and services. Moreover, tourists differ in the information sources they use before making a decision (Moutinho, 1987). As for many consumer product decisions, information acquisition is necessary for selecting a destination and for onsite decisions such as selecting accommodations, transportation, activities, and tours (Fodness and Murray 1998; Gursoy and Chen 2000; Snepenger, Meged, Snelling and Worrall 1990). Information search can be defined as "the motivated activation of knowledge stored in memory or acquisition of information from the environment" (Engel et al 1995). As the definition suggests, a search can be either internal or external. Internal search is based on the retrieval of knowledge from memory, while the other consists of collecting information from the marketplace (Engel et al 1995).

Whenever tourists realize that they need to make a decision, information search is likely to take place, and almost always initially takes place internally such as when previous experiences and knowledge are used as the basis for planning a repeat visit (Chen and Gursoy 2000; Fodness and Murray 1997; Vogt and Fesenmaier 1998). Internal sources include personal experiences, either with the specific destination or with a similar one, and the knowledge accumulated through an ongoing search (Schul and Crompton 1983; Vogt and Fesenmaier,1998). When the internal search provides sufficient information for making a trip decision, external search is obviously unnecessary (Beatty and Smith 1987). However, if the internal search proves insufficient, tourists are likely to also use external sources.

When the internal information search proves inadequate, the travelers may decide to collect additional information from external sources. Travelers tend to use four broad, external information sources when planning their trips. These are (1) family and friends, (2) destination specific literature, (3) media, and (4) travel consultants (Snepenger \& Snepenger, 1993). Uysal et al. (1990) studied the information search behavior of German, French, British and Japanese travelers who travel to the United States. They found that travelers from different countries were more inclined to utilize different types of information with varying frequency. British travelers tended to use travel agents as the main source of external information source followed by family and friends, brochures and pamphlets, and magazine and newspaper articles. 'Family and friends is found to be the most important external information source for German travelers followed by travel agents, brochures and pamphlets, and books and library materials. Like German travelers, 'family and friends is found to be the most important external information source for French travelers, followed by travel agents, brochures and pamphlets, airlines, and articles in magazines and newspapers. Japanese travelers are more likely to use books and other library materials first, then brochures and pamphlets, family and friends, and travel agents.

According to Goossens (2000), "a combination of push and pull information and hedonic responses will motivate tourists to plan a trip". Within this framework, assessing how the experience will feel is an important part in deciding between various leisure services. This may involve daydreams, imagining and emotions. 
Destination choice decision is a function of information available from different sources (Gartner 1993). As a form of protective behavior, travelers can alter their destination choices; modify their travel behavior; or if they decide to continue with their travel plans, they acquire information. According to (Murphy et al 2007), travelers that love risk and want adventure did not seek a lot of information. But those who feared risk not only gathered information but also considered particular vacations and lodging facilities. (Maser and Weiermair 1998) showed that the higher the perceived risk, the more information search occurs, and the more rational decision-making becomes.

Travel motivation Motives are the starting points that launch the decision process (Crompton \& McKay, 1997). Although motivation is only one variable which explains tourist behaviour, it is considered one of the more critical variables as it is the impelling and compelling force behind all behaviour (Baloglu \& Uysal, 1996; Crompton, 1979).

Motivation is one of the important parts of travel consumers' behaviours. Motivation refers synonymously to concepts such as reason, cause, propelling force and purpose to move in a certain direction. In selecting a final destination, tourists pursue one or several reasons (Dann, 1981; Yoon and Uysal, 2005). Given that a temporal stay has associated time and financial limitations, visitors are careful in matching their choices and needs with preferences they are likely to find at a destination. This selective process forms reasons to attain fresh insights and experiences that cannot be found in tourists' usual environments. This behavior motivates escape from established roles and routines to new environments, and for search of new insights in other contexts and cultures. Understanding what motivates an individual's travel behavior and destination choice is vital in predicting their travel decisions and future travel patterns (Jang and $\mathrm{Wu}, 2006$ ) and it can be used to develop more appropriate strategies to attract them. Page and Connell (2006) stated that motivation as a subject is an integral part of the study of consumer behaviour in tourism. Mountinho (1987), as cited in Page (2009), defined motivation as a "state of need, a condition that exerts a push on the individual towards certain types of action that are seen as likely to bring satisfaction". It indicates the intrinsic reasons why the individual is embarking on a particular trip Weaver and Lawton, 2002). This psychological concept refers to tourists and the reasons why they embark on a particular trip. It is too, directly linked to the demand for tourism, which can affected by a range of factors, and to consumer/tourist behaviour, which does not only affect the initial purchase but also the tourist experience as well as future decisions (Lomine and Edmunds, 2007).

Travel Constraints A number of researchers have noticed the impact of constraints in the decision-making process. They argue that motivation is only one of many variables which explain tourists' preference as to destinations. Other variables such as travellers' perceived inhibitors and situational constraints in their decision making should also be considered when destination marketers determine marketing strategies (Baloglu \& Uysal, 1996; Oh et. al, 1995 ; Pyo et. al, 1989). The constraints research started from early barriers studies in which questions about barriers to participation began to be asked explicitly. Then it developed a change of terminology. The term "constraints" is preferred to "barriers", because the latter fails to capture the entire range of explanations of constrained leisure behaviour (Jackson, 1988). Moreover, the word - barrier\| tends to direct researchers' attention toward only one type of constraints, that which intervenes between preference and participation (Crawford \& Godbey,1987). Meanwhile, researchers shifted the focus of their attention to constraints which are not only physical and external to the individual (e.g., facility and resource), but also internal (e.g., psychological and economic) and social (e.g., marital, family and other interpersonal relations).

The TPB predicts that there is a range of factors that can potentially influence or constrain travel intentions. More specifically, what others think or do (often referred to as subjective norms) as well as constraints or barriers, and the control over constraints or barriers (Ajzen, 1991) have the potential to impact travel intentions. First, intentions to travel are likely to be influenced by what others, who form a reference group for the consumer, think or do in regard to the target behaviour. It is also recognized that there may be a range of constraints that impede or prevent someone from travelling. For Chinese tourists, factors such as language, distance, cost or Government control (e.g. obtaining a visa) might be some such impediments. Overcoming such constraints or having a feeling of a sense of perceived control over the target behaviour is also likely to be important in determining travel intentions. Ajzen (1991) has pointed out that control beliefs can obstruct or make possible a particular behaviour. A consumer's perceptions of having or not having the resources (e.g. time or money) to engage in specific travel behaviour will impact travel intentions. Perceived control has been identified as an important construct for predicting intention to visit a tourist destination (see, Lam \& Hsu, 2006; Sparks, 2007).Similarly, leisure researchers have identified structural barriers such as time, financial resources, season, climate or family life cycle that can inhibit participation in certain activities (Crawford, Jackson \& Godbey, 1991). For Chinese tourists, key constraints could include the currency exchange rate of the Yuan, cost of travel, perceptions of safety in travel, length of travel time and Government visa restrictions.

\section{Holiday characteristics}

Holiday characteristics constitute variables such as decision-making time taken to select a destination, travel companion, past travel experience, length of stay, holiday organization mode, type of accommodation used, type of transport, budget of travel and activities undertaken on holiday. This kind of information is frequently used in tourism research in order to identify the travel behavior characteristics of tourists (Huh, Uysal, \& McCleary, 2006; Kozak et al., 2004). 
Holiday travel characteristics can also be extracted from prior travel experiences (Beerli \& Martin, 2004). Lehto et al, (2004) determined that prior travel experience, in the form of types of holidays, activities pursued during holidays, frequencies of holidays, lengths of holidays, and interactions across these factors, was a significant predictor of future holiday activity participation and expenditures.

\section{Domestic tourism}

Domestic tourism is the backbone of economic development for a country. For instance, domestic tourists support small-scale enterprises and informal sectors in developing countries because they purchase more locally produced goods and services (Scheyvens, 2007). Domestic tourism, particularly in developing countries, is critical for the tourism industry to thrive. With a focus on the domestic tourism market, countries are able to diversify their tourism products and appeal to a wider target audience (Mazimhaka, 2006). One of the major benefits of domestic tourism is that while domestic tourists often spend less money per visit, they travel more often and bring greater economic growth particularly to the local communities. Domestic tourists contribute more directly to the services offered by the local population, thereby contributing to the informal tourism sector, maintaining the strength of the industry, promoting propoor tourism and as a result, aiding in the poverty alleviation efforts of the country. As previously shown, a survey of literature on tourism in developing countries indicates that countries like South Africa, Nigeria, Kenya, China and India have realised the significant benefits of improving the domestic tourism market, especially with regard to the growth of this market (Ghimire and Li, 2001 in Mazimhaka, 2006). Undoubtedly, these efforts result in economic benefits for local communities and a more sophisticated product for international consumers.

Another benefit of the development of a domestic tourism industry is that domestic tourists are not as often deterred from travel based on political, social or economic problems in the region as are international tourists. Rao and Suresh (2001, p.208) point out that "domestic tourism is not vulnerable to bad publicity, internal security problems and poor infrastructure". Yet, while the importance of domestic tourism has been widely acknowledged, significant research and information on the current role of domestic tourism is still lacking. This is a major constraint to the growth of domestic tourism, and this gap stems from the fact that most developing countries view domestic tourism as secondary to attracting the international market, which brings in badly needed foreign currency (Mazimhaka, 2006). Mazimhaka (2007) argued that, in Rwanda, a lack of variety of tourism products offered to the local travellers has caused a significant barrier to the development of Rwandan domestic tourism. Furthermore, the costs of domestic travel could be the cause of this concern. For instance, Sindiga (1996) asserted that Kenyans could not afford to pay for domestic tourism facilities due to the high costs of travel in Kenya. Similarly, Wen (1997) has noticed that Chinese domestic travellers tend to be frugal in spending because of relatively high travel costs in China. Unfortunately, the growth of domestic tourism is still lacking in many developing countries because it continues to be viewed as a luxury that many locals cannot afford. Developing countries faced with economic adversity will naturally have difficulty generating a significant local tourist population, though in many of these same countries, a sizeable middle-class exists and has the potential to participate in and make use of their country's tourist attractions (Mazimhaka, 2006).

Domestic tourism throughout the world is a predominant but invisible portion of total tourism activity. The lack of commonly accepted and/or used definitions of domestic travel activity is largely responsible for this ignorance. Available domestic tourism data are mostly in the form of number of trips to destinations beyond a certain minimum distance from the normal place of residence, and involving at least one overnight stay. Other data include same-day visitors. And in case no such data format is available researchers resort to either the number of registered guests in hotels, etc. or the ratio between the number of overnight stays and the average length of stay (Bigano et al. 2004). In the past two decades, domestic tourism has been rather neglected in tourism analysis, the most of the papers focusing on international tourists, although the domestic tourism accounts more than $50 \%$ of all tourist movements. Among the studies that concern about domestic tourism we mention Massidda and Etzo (2012) who investigated the main determinants of Italian domestic tourism demand as measured by regional bilateral tourism flows. However tourist actual choices appear also to be influenced by past experiences and by regional differences in the quality of the wider environment. Additionally it appears that, for Italian tourists, domestic and international destinations behave as substitutable goods. Unfortunately, the previous research has been ignored the behavior and the needs of the residents as potential tourists. Because the understanding of the domestic potential tourist market remains inadequate and knowing that influence factors of residents' travel decision is crucial in predicting their future travel pattern, this paper tries to pay attention about importance of profiling the needs of residents as potential domestic tourists.

\section{Domestic tourism in Egypt}

Despite the unrest in the country, domestic tourism witnessed improvement versus 2012 especially to the top tier hotels which were usually expensive to stay in. The growth comes in response to the initiatives from hotels and Egypt Air that offer reduced rates and packages to stimulate domestic tourism. While the luxury domestic tourism increased, the frequency of domestic tourism for touristic attractions or other cities in Egypt decreased, especially from the middle and lower strata of society. This had to do with the high inflation rate and hence lower disposable income. Furthermore, the security conditions in some cities reduced the day trips to touristic attractions. Domestic tourism has increased by $3 \%$ from 2012, to a total of 8.5 million trips compared to 8.3 million trips in 2012. It is predicted that if hotels' offers continue and security is restored, domestic trips will increase at a CAGR of $10 \%$ over the forecast period, to almost 14 
million trips in 2018 (Euromonitor International Report 2013). Domestic travel spending generated 66.9\% of direct Travel \& Tourism GDP in 2013 compared with $33.1 \%$ for visitor exports (ie foreign visitor spending or international tourism receipts). Domestic travel spending raised to EGP93.9bn with an increase of $1.1 \%$ and is expected to grow to EGP150.3bn with $4.8 \%$ pa by 2024. Domestic Travel \& Tourism Spending reached to 13.2 (US\$ bn) in 2013 according to World Travel and Tourism Council Data, 2013. Number of Domestic Trips \& Overnights reached to 16.6 million according to Tourism Satellite Account Unit, Ministry of Tourism 2013.

\section{Research Objectives and Framework}

The research aims at finding answers to the following questions:

1- What are different factors affecting the decision of visitors to go on domestic holidays in Egypt?

2- How are these factors affecting the decision of Egyptian domestic holidays?

The research aims to analyze Egyptian pleasure travellers and understanding visitor's profile, behaviour and their decision-making will help to predict future travel patterns and undertake effective marketing campaign. The specific objectives are:

1) To profile the local tourists and its influence on domestic destination choice.

2) To examine the relationships that exists between travel behaviour and destination choice.

3) To determine the travel-related characteristics such as mode of transportation, type of accommodation as well as travel companions used to make travel decisions.

Lang, O'Leary and Morrison (1997) examine the destination choice of Taiwanese outbound travelers. They find that the choice of Asia-Pacific destinations is affected by socio-demographics, travel characteristics, and psychographic attributes. All the demographic variables, except age and sex, present significant differences between 'within-Asia' and 'out-of-Asia' travel; and the most important variables for differentiating within- and out of-Asia travelers are education, income (socio-demographic variables), package tour, length of trip, total cost of trip, trip party size (trip-related variables), 'safety net', 'cost and experience', 'budget travel', and 'value and lifestyle' (benefit factors).

The following framework of pleasure travel decision was proposed (Figure 3) based on the literature. As the figure shows, there are three determinant factors affecting the decision of domestic tours: first, visitor profile which includes demographic features of guests such as age, gender, purpose of trip, occupancy, and education. Second, visitor behavior which is influenced by several variables: travel motivation, travel constraints and Information search behavior. Third, Holiday characteristics which constitute variables such as travel companion, length of stay, type of accommodation used, mode of transport, Travel arrangement, travel times and activities undertaken on holiday.

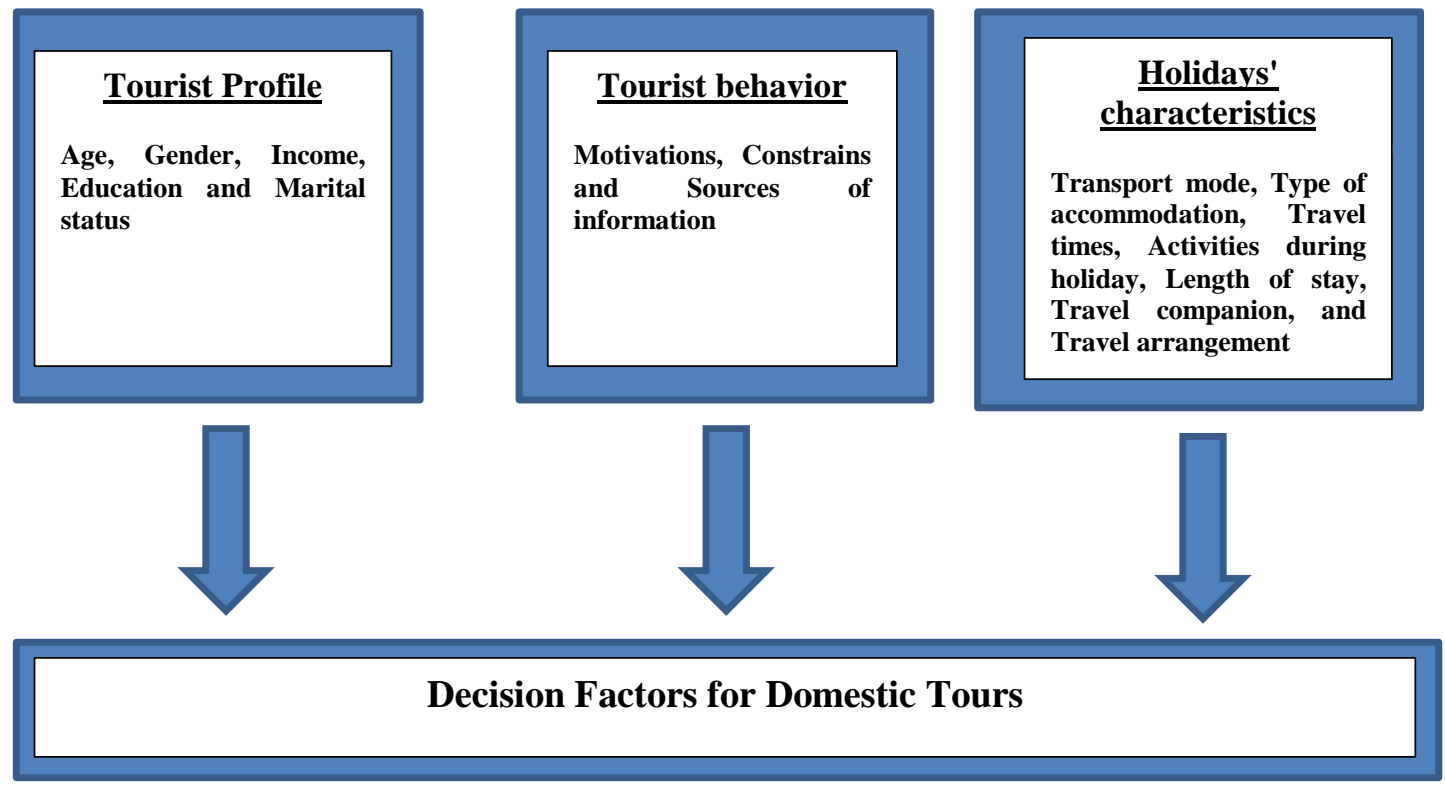

Figure (3) Research model

Source: The researcher 
The research hypotheses in this study are selected on the basis of the research model, in order to analyze the influential relationship among determinants affecting domestic travel decision-making.

For the purpose of the study, the following hypotheses are:

H1: visitor profile is significantly affecting the decision of visitors to go on domestic holidays

$\mathrm{H} 2$ : visitor behavior is significantly affecting the decision of visitors to go on domestic holidays

H3: visitor travel-related characteristics is significantly affecting the decision of visitors to go on domestic holidays

\section{Methodology and Data Analysis}

This exploratory, quantitative study on Egyptian domestic travellers is rather limited. A questionnaire was developed for data collection purposes and a survey has been running on August-November 2014. The questionnaire consists of three parts namely preferred travel-related characteristics, travel attitude and behavior, travel planning and demographic. A pilot study was also conducted to test the questionnaire. The preliminary test managed to secure 25 respondents and a more refined questionnaire was developed from the suggestions and comments from the respondents. This paper reports on initial findings of the survey a total of respondents 353 at major destinations in Egypt like SharmElsheik, Hurghada, Alexandria and North cost. Random sampling method was employed for this study. The survey employed self-administered questionnaire, distributed and monitored to approach domestic tourists found at popular spots like beaches, malls, Hotels and resorts.

Descriptive analysis such as frequency, mean and standard deviation were conducted to examine respondents' demographic profiles, purpose of travel and holiday choice related characteristics, affected factors, decision-making, attitudes to travel and destination choice. SPSS (Statistical Program for Social Sciences) was the statistical analysis package used to analyze findings.

\section{Results and Discussion}

Demographic profiles From Table 1, The findings revealed that $50.4 \%$ of respondents are female, $49.6 \%$ are males, $58.5 \%$ of respondents aged between 18 to 29 years, $22.7 \%$ of them are between 30 to 39 years, $18.8 \%$ of them are 40 years or above. $68.4 \%$ are studying at college level, $26.6 \%$ are postgraduate students, while $51 \%$ of respondents are in high school level of education. Most respondents are single (51.9\%), 37.9\% are married and $10.1 \%$ have different marital status. $85.7 \%$ of respondents have household income below 25000 L.E., $8.1 \%$ have household income ranges from L.E. 25000 to 34999 L.E., and 6.2 of respondents have household income exceeds L.E. 34999. It is clear that the sample of the study include respondents with different age categories, genders, education levels, marital status, and household income.

Table (1). Statistics of respondents' personal data

\begin{tabular}{|l|l|l|l|l|l|}
\hline Age & $\mathbf{\%}$ & Education & $\boldsymbol{\%}$ & Household income & \% \\
\hline $18-29$ & 58.5 & postgraduate & 26.6 & Under L.E. 25,000 & 85.7 \\
\hline $30-39$ & 22.7 & College & 68.4 & L.E.25,000 - L.E.34,999 & 8.1 \\
\hline $40-49$ & 12.8 & High school & 5.1 & L.E.35,000 - L.E.49,999 & 2.7 \\
\hline $50-59$ & 1.5 & & L.E.50,000 - L.E.74,999 & 1.8 \\
\hline $60-69$ & 4.5 & Marital Status & $\%$ & L.E.75,000- L.E.99,999 & 1.5 \\
\hline Gender & $\%$ & Single & 51.9 & L.E.100,000 or more & $\cdot .3$ \\
\hline Male & 49.6 & Married & 37.9 & & \\
\hline Female & 50.4 & Other & 10.1 & & \\
\hline
\end{tabular}

\section{Behaviour and attitude to travel}

Motivations: From Table 2, there are a number of reasons motivate respondents to take domestic holidays, using mean values of respondents' opinions, it is found that respondents agree (mean value of 4.41) with 'rest and relax'. The second reason based on mean values is 'escaping from daily life/ routine/ pressure' (4.22). Spending time with family comes next with a mean value of 4.10. 'Having fun/ maintaining friendships' is the fourth reason of traveling on domestic holidays (mean value $=3.91$ ). This is followed by 'experiencing different climate, landscape and nature' with a mean value of 3.90. 'Experiencing thrills/ excitement' ranks the sixth reason of traveling (mean value of 3.52). However, respondents have neutral opinions on 4 reasons, they are 'gaining a new perspective on life', 'learning new things', 'developing personal interests' and 'having other to know they are there' with mean values of 3.23, 3.19. 3.19, and 2.60 respectively.in total and based on the grand mean value of 3.63, respondents agree with the above mentioned reasons to travel on domestic holidays. The results are reliable where Cronbach's alpha is 0.773. Standard deviation values are within limits. 
Table (2) Motivations for travel on domestic holiday

\begin{tabular}{|c|c|c|c|c|c|c|c|}
\hline Motivations & $\begin{array}{l}\text { Strongly } \\
\text { Disagree } \\
\quad(\%)\end{array}$ & $\begin{array}{c}\text { Disagree } \\
(\%)\end{array}$ & $\begin{array}{c}\text { Neither } \\
\text { Agree nor } \\
\text { Disagree } \\
(\%)\end{array}$ & $\begin{array}{c}\text { Agree } \\
(\%)\end{array}$ & $\begin{array}{l}\text { Strongly } \\
\text { Agree } \\
(\%)\end{array}$ & Mean & $\begin{array}{c}\text { Std. } \\
\text { Deviation }\end{array}$ \\
\hline $\begin{array}{l}\text { Escape from daily } \\
\text { life/routine/pressure }\end{array}$ & 6.9 & 4.5 & 4.2 & 29.0 & 55.5 & 4.22 & 1.16 \\
\hline Rest and relax & 2.7 & 2.1 & 1.8 & 38.2 & 55.2 & 4.41 & 0.85 \\
\hline $\begin{array}{c}\text { Experience thrills/ } \\
\text { excitement }\end{array}$ & 9.9 & 11.9 & 17.6 & 37.9 & 22.7 & 3.52 & 1.24 \\
\hline $\begin{array}{l}\text { Have fun/ Maintain } \\
\text { friendship }\end{array}$ & 4.5 & 4.2 & 11.9 & 54.6 & 24.8 & 3.91 & 0.97 \\
\hline Spend time with family & 5.1 & 5.1 & 8.7 & 37.0 & 44.2 & 4.10 & 1.09 \\
\hline Learn new things & 10.1 & 20.6 & 22.1 & 34.9 & 12.2 & 3.19 & 1.19 \\
\hline $\begin{array}{l}\text { Develop my personal } \\
\text { interests }\end{array}$ & 8.7 & 20.3 & 25.7 & 34.0 & 11.3 & 3.19 & 1.15 \\
\hline $\begin{array}{c}\text { Gain a new perspective on } \\
\text { life }\end{array}$ & 11.3 & 10.1 & 35.2 & 31.0 & 12.2 & 3.23 & 1.14 \\
\hline $\begin{array}{c}\text { Have others know that I } \\
\text { have been there }\end{array}$ & 26.6 & 23.9 & 18.2 & 26.0 & 5.4 & 2.60 & 1.27 \\
\hline $\begin{array}{c}\text { Experiencing different } \\
\text { climate, landscape and } \\
\text { nature }\end{array}$ & 2.7 & 8.4 & 6.3 & 61.5 & 21.2 & 3.90 & 0.92 \\
\hline Grand Mean & & & & & & 3.63 & \\
\hline
\end{tabular}

Constrains: Table 3 shows the importance level of factors affecting respondents' decision to go on domestic holidays. Looking at mean values of opinions, it is concluded that respondents rank 'Safety' as the highest factor affecting the decision of respondents to go on domestic holidays (mean value of 4.34). Health issues come second in the list of important factors with a mean value of 4.28. Political stability is the third important factor affecting the decision of taking holiday (mean value of 4.14). Shortage of money is the fourth factor (mean of 3.90), it is followed by lack of time (3.89), destination (3.87), accommodation (3.80), loss of property (3.78), value for money (3.70), and weather (3.67). However, respondents have neutral opinions on 3 factors; these are other tourists (3.10), travel fatigue (3.05), and cultural risk (2.96). The results are reliable where Cronbach's alpha is 0.872 . Standard deviation values are within limits.

Table (3) Factors affecting decision of taking domestic holiday

\begin{tabular}{|c|c|c|c|c|c|c|c|}
\hline Factors & 预高 & 章 & 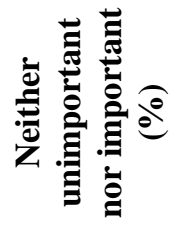 & 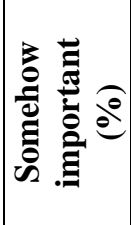 & 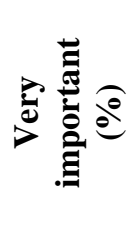 & Mean & $\begin{array}{l}\text { Std. } \\
\text { Deviation }\end{array}$ \\
\hline Safety & 11.3 & .6 & 2.1 & 14.3 & 71.6 & 4.34 & 1.29 \\
\hline Health & 9.3 & 2.7 & 2.7 & 21.5 & 63.9 & 4.28 & 1.24 \\
\hline Political stability & 3.6 & 6.0 & 14.9 & 24.2 & 51.3 & 4.14 & 1.10 \\
\hline Shortage of Money & 6.3 & 8.7 & 16.1 & 27.2 & 41.8 & 3.90 & 1.22 \\
\hline Lack of time & 9.0 & 5.7 & 9.9 & 38.2 & 37.3 & 3.89 & 1.22 \\
\hline Destination & 5.1 & 14.0 & 8.1 & 34.6 & 38.2 & 3.87 & 1.21 \\
\hline Value for Money & 6.6 & 7.2 & 26.9 & 28.7 & 30.7 & 3.70 & 1.17 \\
\hline Travel fatigue & 9.9 & 25.4 & 23.0 & 33.4 & 8.4 & 3.05 & 1.15 \\
\hline Cultural risk & 7.5 & 30.7 & 31.3 & 19.7 & 10.7 & 2.96 & 1.11 \\
\hline Weather & 5.4 & 19.1 & 6.0 & 41.8 & 27.8 & 3.67 & 1.22 \\
\hline $\begin{array}{l}\text { Loss of property (eg, } \\
\text { theft, loss of luggage) }\end{array}$ & 7.2 & 15.5 & 9.3 & 28.7 & 39.4 & 3.78 & 1.31 \\
\hline Accommodation & 4.8 & 10.4 & 15.8 & 37.9 & 31.0 & 3.80 & 1.13 \\
\hline Other tourists & 7.2 & 24.5 & 31.0 & 25.7 & 11.6 & 3.10 & 1.12 \\
\hline
\end{tabular}

Information search behavior looking at Table 4, respondents mentioned that word of mouth is the first source of information (75.5\%) when they start their travel planning process. Internet comes second $(66.3 \%)$, 59.4\% of respondents obtain information from their previous visits. Travel agents are the fourth source of information for $39.4 \%$ 
of respondents. Next is attractions' websites (23.9\%), followed by brochures (23.6\%), television advertising (22.4\%), newspaper advertising (17\%), attractions newsletter (4.8\%), and radio advertising (0.9\%). In addition, $34 \%$ of respondents have never used travel agent in travel planning, while $29 \%$ of respondents used them once, $20.6 \%$ used travel agents some time, and $16.4 \%$ used them most of time.

Table (4) Descriptive statistics of travel Information search

\begin{tabular}{|c|c|}
\hline $\begin{array}{l}\text { Main sources of information while } \\
\text { choosing your domestic holiday? }\end{array}$ & $\%$ \\
\hline Word of mouth (friends, relatives) & 75.5 \\
\hline Brochure & 23.6 \\
\hline Newspaper advertising & 17.0 \\
\hline Television advertising & TY. \\
\hline Radio advertising & $\because .9$ \\
\hline Attractions' website & rT.q \\
\hline Internet & 77.4 \\
\hline Attractions newsletter & $\varepsilon . \wedge$ \\
\hline Travel agents & rq. \\
\hline From previous visits & 09.5 \\
\hline
\end{tabular}

\section{Holiday choice related characteristics}

\section{Travel times, length of stay, type of accommodation and mode of transportation}

Looking at Table 5, it is depicted that $37.3 \%$ of respondents goes Once a week or more on a family outing within the last year, $29.9 \%$ goes once a month, $17 \%$ goes once every 3 months or more, $14.4 \%$ goes once every less than a week. As for taking domestic holidays as a family group within the last year, 51\% went on one holiday, 2-3 times for 31.6\% of respondents, and $9.6 \%$ of respondents went on 4 holidays or more. A percentage of $36.7 \%$ of respondents stays a week on holiday, $32.5 \%$ stays 5 nights, and $30.8 \%$ of them stay less than 5 nights. Hotels or motels were the most preferred accommodation type of respondents (48.1\%), 24.2\% of respondents' preferred rented house/ flat, $19.1 \%$ of respondents have their own holiday home, $8.7 \%$ of respondents stay in other types of accommodation. $37 \%$ of respondents use car to travel to destination, while $77 \%$ of them use car on holiday. $28 \%$ of respondents prefer air as the second means of travel to destination while $11.9 \%$ prefer coach on holiday travel.

Table (5) Descriptive statistics of travel-related characteristics

\begin{tabular}{|c|c|c|c|}
\hline Characteristics & Attributes & Frequency & Percent \\
\hline \multirow{8}{*}{$\begin{array}{l}\text { Approximately how often did you go } \\
\text { on a family outing within the last year? }\end{array}$} & Everyday & 2 & 0.6 \\
\hline & Once & 18 & 5.4 \\
\hline & Once a fortnight & 28 & 8.4 \\
\hline & Once a week or more & 125 & 37.3 \\
\hline & Once a month & 100 & 29.9 \\
\hline & Once every 3 months & 35 & 10.4 \\
\hline & Once every 6 months & 22 & 6.6 \\
\hline & None & 5 & 1.5 \\
\hline \multirow{6}{*}{$\begin{array}{l}\text { How many domestic family holidays } \\
\text { did you take as a family group within } \\
\text { the last year? }\end{array}$} & Once a year & 171 & 51.0 \\
\hline & $2-3$ times & 106 & 31.6 \\
\hline & 4-6 times & 20 & 6.0 \\
\hline & 7-10 times & 5 & 1.5 \\
\hline & more than 10 times & 7 & 2.1 \\
\hline & None & 26 & 7.8 \\
\hline \multirow{4}{*}{$\begin{array}{l}\text { How many nights do you expect to } \\
\text { stay away from your usual place of } \\
\text { residence during your domestic } \\
\text { holiday? }\end{array}$} & 2 nights & 33 & 9.9 \\
\hline & 3 nights & 70 & 20.9 \\
\hline & 5 nights & 109 & 32.5 \\
\hline & Week & 123 & 36.7 \\
\hline \multirow{6}{*}{$\begin{array}{l}\text { What type of accommodation do you } \\
\text { mostly stay in during your domestic } \\
\text { holiday? }\end{array}$} & Own Holiday Home & 64 & 19.1 \\
\hline & Hotel or Motel & 161 & 48.1 \\
\hline & Boat & 6 & 1.8 \\
\hline & Rented House/Flat & 81 & 24.2 \\
\hline & Camping & 6 & 1.8 \\
\hline & Other & 17 & 5.1 \\
\hline Mode of travel to the destination & Car & 124 & 37.0 \\
\hline
\end{tabular}




\begin{tabular}{|l|l|c|c|}
\hline \multirow{5}{*}{ Mode of travel on holiday } & Bus / Coach & 85 & 25.4 \\
\cline { 2 - 4 } & Train & 27 & 8.1 \\
\cline { 2 - 4 } & Air & 95 & 28.4 \\
\cline { 2 - 4 } & Motor-bike & 4 & 1.2 \\
\hline & Car & 258 & 77.0 \\
\cline { 2 - 4 } & Bus / Coach & 40 & 11.9 \\
\cline { 2 - 4 } & Train & 3 & .9 \\
\cline { 2 - 4 } & Air & 12 & 3.6 \\
\cline { 2 - 4 } & Boat & 10 & 3.0 \\
\cline { 2 - 4 } & Motor-bike & 12 & 3.6 \\
\hline
\end{tabular}

Activities undertaken on holiday From Table 6 illustrates the importance level of activities practiced on holidays and how this contributes to enjoyment level of the holiday. Using mean values of respondents' opinions, it is found that respondents rank 'coastal location' as the first important activity contributes to level of enjoyment of holidays (mean value of 4.14), 'swimming/ sunbathing' and 'a warm, sunny climate' occupy the second and third ranks of importance (with mean values of 4.01). 'Dine at cafe or restaurants' comes next with a mean value of (3.88). 'Sightseeing in cities' and 'Enjoying scenery' are the fifth and sixth important activities on domestic holidays (mean value of 3.86). 'Eating seafood' is the seventh important activity (mean value of 3.71) while 'meeting people' is the eighth important activity' (with mean value of 3.70). However, respondents have neutral opinions on the importance level of ....activities, these are shopping (mean value of 3.43), amusement/ theme parks (3.40), water sports (3.28), visiting heritage/ historical sites (3.26), museum/ gallery (3.24), snorkeling \& scuba diving (3.15), visiting small towns and villages (2.92), environmental/ ecological excursions (2.79), and disco/ night clubs (2.70). In addition, respondents think that 'go fishing' is unimportant activity (mean value of 2.48). The results are reliable where Cronbach's alpha is 0.826 . Standard deviation values are within limits.

Table (6) The importance of activities practiced on domestic holiday

\begin{tabular}{|c|c|c|c|c|c|c|c|}
\hline Activities & 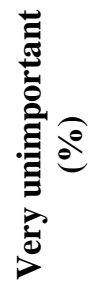 & 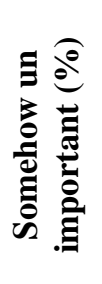 & 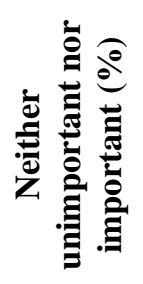 & 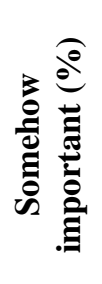 & 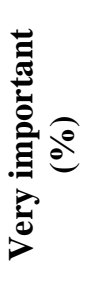 & Mean & $\begin{array}{c}\text { Std. } \\
\text { Deviation }\end{array}$ \\
\hline Shopping & 18.8 & 14.3 & 8.1 & 31.9 & 26.9 & 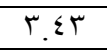 & 1.00 \\
\hline Sightseeing in cities & 3.3 & 15.2 & 9.3 & 36.7 & 35.5 & 3.86 & 1.70 \\
\hline Dine at cafe or restaurants & 4.5 & 13.1 & 7.5 & 39.4 & 35.5 & $r . \wedge \wedge$ & 1.17 \\
\hline Swimming/ Sunbathing & 4.2 & 9.0 & 14.0 & 27.2 & 45.7 & $\varepsilon .+1$ & $1.1 \mathrm{~V}$ \\
\hline Amusement/ Theme Parks & 5.7 & 17.3 & 23.0 & 39.4 & 14.6 & r.s. & 1.11 \\
\hline Water Sports (diving) & 15.5 & 19.1 & 12.8 & 26.9 & 25.7 & r.th & $1 . \varepsilon r$ \\
\hline Visiting heritage/ historical sites & 16.4 & 16.7 & 10.7 & 36.4 & 19.7 & T.YT & $1 . \Gamma \wedge$ \\
\hline Disco/ Night clubs & 29.6 & 23.6 & 8.7 & 23.3 & 14.9 & r.V. & $1 . \leqslant V$ \\
\hline $\begin{array}{l}\text { Environmental/Ecological } \\
\text { excursions }\end{array}$ & 17.0 & 26.3 & 24.2 & 26.0 & 6.6 & r.vq & 1.19 \\
\hline Visiting small towns \& villages & 13.1 & 26.9 & 23.6 & 27.5 & 9.0 & r.9Y & 1.19 \\
\hline Eat seafood & 10.7 & 6.6 & 16.4 & 33.7 & 32.5 & $r . v 1$ & $1 . Y \wedge$ \\
\hline Go Fishing & 29.9 & 27.8 & 15.8 & 17.6 & 9.0 & $r . \Sigma \Lambda$ & $1 . r Y$ \\
\hline Snorkelling \& Scuba diving & 18.8 & 17.6 & 16.1 & 24.5 & 23.0 & 5.10 & $1 . \leqslant \varepsilon$ \\
\hline A warm, sunny climate & 4.2 & 3.9 & 16.4 & 37.9 & 37.6 & $\varepsilon .1$ & $1 . \cdot \varepsilon$ \\
\hline Coastal location & 1.8 & 8.1 & 11.0 & 32.2 & 46.9 & ะ.1 & $1 .+1$ \\
\hline Meet people & 3.0 & 17.6 & 14.9 & 35.8 & 28.7 & r.v. & 1.10 \\
\hline Museum/ Gallery & 11.3 & 17.0 & 18.5 & 42.7 & 10.4 & T.YE & 1.19 \\
\hline Enjoy scenery & 6.0 & 11.0 & 10.4 & 35.8 & 36.7 & r.Aт & $1 . Y \cdot$ \\
\hline
\end{tabular}

\section{Travel companion and travel arrangements}

From Table 7 , it is found that $50.4 \%$ of respondents travel with friends or with relatives, $43.6 \%$ of them travel with spouse and children, $15.2 \%$ travel with spouse only, 3.9\% travel alone, and $2.1 \%$ travel with children. Asking about the method of booking holidays, respondents claimed that booking direct with holiday providers comes first (59.1\% of respondents), next is booking via travel agents (27.5\%), and online booking comes last (with $13.4 \%$ of respondents). 
Table (7) Descriptive statistics of the travel companions and booking methods

\begin{tabular}{|l|l|l|l|}
\hline With whom do you usually travel? & $\%$ & How do you usually book your holidays? & $\%$ \\
\hline Alone & 3.9 & Directly with the holiday providers & 59.1 \\
\hline With spouse & 15.2 & Online with travel websites & 13.4 \\
\hline With spouse and children & 43.6 & With travel agencies & 27.5 \\
\hline With children & 2.1 & & \\
\hline With other friends or relatives & 50.4 & & \\
\hline
\end{tabular}

From table $834 \%$ of respondents have never used travel agent in travel planning, while $29 \%$ of respondents used them once, $20.6 \%$ used travel agents some time, and $16.4 \%$ used them most of time.

Table (8) Descriptive statistics of travel planning concerns

\begin{tabular}{|l|l|}
\hline $\begin{array}{l}\text { Who usually organize your travel } \\
\text { arrangements? }\end{array}$ & $\%$ \\
\hline Myself & $\leq \uparrow$ \\
\hline Family Member(s) & $\leq 9.9$ \\
\hline Other (please specify) & $\varepsilon . r$ \\
\hline $\begin{array}{l}\text { How often do you use a travel } \\
\text { agent when planning a vacation }\end{array}$ & $\%$ \\
\hline Most of the time & $17 . \varepsilon$ \\
\hline About half the time & $r \cdot .7$ \\
\hline Once in a while & $r .^{\cdot}$ \\
\hline Never & $r \varepsilon . \cdot$ \\
\hline
\end{tabular}

Asking respondents about the budget they could reduce when planning their holidays, Table 9 shows that $49 \%$ of respondents said they can reduce the budget of cultural visits, $36.1 \%$ of respondents could reduce the budget of transportation. Food comes next for $35.5 \%$, followed by accommodation (27.2\% of respondents), and leisure activities come last for $26 \%$ of respondents. In addition, asking respondents to rate the booking in advance of their holiday components, it is found that $36.9 \%$ of respondents prefer to book the hotel in advance, $31.9 \%$ of respondents book some specific nights in advance, $28.4 \%$ of them rent a car in advance, $21.2 \%$ of them book train in advance, and $27.5 \%$ book entertainment places ticket in advance, while $4.5 \%$ of respondents do not book any component in advance.

Table (9) Descriptive statistics on budget and booking holidays in advance

\begin{tabular}{|c|c|c|c|}
\hline $\begin{array}{l}\text { Which budget could you reduce to } \\
\text { spend less for your holidays? }\end{array}$ & $\%$ & $\begin{array}{l}\text { What would you like to book in } \\
\text { advance for your holiday }\end{array}$ & $\%$ \\
\hline Cultural visits & 49.0 & Book the hotel & 63.9 \\
\hline Transport & r..1 & Book specific nights (First/ last night) & 31.9 \\
\hline Food & ro.0 & Rent a car & $r \wedge . \varepsilon$ \\
\hline Accommodation & TV.Y & Train or boat tickets & YI. \\
\hline \multirow[t]{2}{*}{ Leisure activities } & rч.• & Tickets for entertainment places & TV.O \\
\hline & & Nothing & $\varepsilon .0$ \\
\hline
\end{tabular}

Testing Hypothesis

H1: visitor profile is significantly affecting the decision of visitors to go on domestic holidays

Test the first hypothesis of the study: visitor profile is significantly affecting the decision of visitors to go on domestic holidays. From Table 10 and using Chi-square test, it is found that 2 out of 4 attributes are significantly affecting visitors decisions of taking domestic tours, these factors are: age $\left(X^{2}=11, D F=2\right.$, and $\left.P<0.05\right)$, and gender $\left(X^{2}=17.1\right.$, $\mathrm{DF}=2$, and $\mathrm{P}<0.01)$. However, 2 attributes were found not significantly affecting the decision of taking domestic tours. These attributes are: education level $\left(\mathrm{X}^{2}=5.5, \mathrm{DF}=2\right.$, and $\left.\mathrm{P}<0.01\right)$, and marital status $\left(\mathrm{X}^{2}=0.7, \mathrm{DF}=2\right.$, and $\left.\mathrm{P}>0.05\right)$. Therefore, it can be concluded that the first hypothesis is supported. 
Table (10) Chi-square statistics of visitor profile and taking domestic tours

\begin{tabular}{|l|l|l|l|l|}
\hline Visitor profile & Chi-Square & DF & Sig. & Result \\
\hline Age & 11.005 & 4 & .027 & Supported \\
\hline Gender & 17.071 & 1 & .000 & Supported \\
\hline Education & 5.530 & 2 & .063 & Not Supported \\
\hline Marital Status & .862 & 2 & .650 & Not Supported \\
\hline
\end{tabular}

H2: visitor behavior is significantly affecting the decision of visitors to go on domestic holidays

From Table 11, and testing the second hypothesis of the study that there are different motives that affect visitor decisions of taking domestic tours, using Chi-square of independence to test the independence between factors, it is revealed that 9 out of 10 motives affect visitor decisions to go on domestic tours, these motives are: escape from daily life/routine/pressure $\left(\mathrm{X}^{2}=63.8, \mathrm{DF}=2\right.$, and $\left.\mathrm{P}<0.01\right)$, rest and relax $\left(\mathrm{X}^{2}=48.5, \mathrm{DF}=2\right.$, and $\left.\mathrm{P}<0.01\right)$, having fun/ maintaining friendship $\left(X^{2}=26, D F=2\right.$, and $\left.P<0.01\right)$, spending time with family $\left(X^{2}=25.9, D F=2\right.$, and $\left.P<0.01\right)$, learning new things $\left(X^{2}=13.5, D F=2\right.$, and $\left.P<0.01\right)$, developing personal interests $\left(X^{2}=31.5, D F=2\right.$, and $\left.P<0.01\right)$, gaining a new perspective on life $\left(X^{2}=52.5, D F=2\right.$, and $\left.P<0.01\right)$, having others know that $I$ have been there $\left(X^{2}=10.5, D F=2\right.$, and $\mathrm{P}<0.01)$, and experiencing different climate, landscape and nature $\left(\mathrm{X}^{2}=18.3, \mathrm{DF}=2\right.$, and $\left.\mathrm{P}<0.01\right)$, while experiencing thrills/ excitement found not significant $\left(\mathrm{X}^{2}=2.6, \mathrm{DF}=2\right.$, and $\left.\mathrm{P}>0.05\right)$. In sum, it can be concluded that the second hypothesis is supported.

Table (11) Chi-square statistics of motives of travel and taking domestic tour

\begin{tabular}{|l|c|c|l|l|}
\hline Motivations & Chi-Square & DF & Sig. & Result \\
\hline Escape from daily life/routine/pressure & 63.825 & 2 & .000 & Supported \\
\hline Rest and relax & 48.425 & 2 & .000 & Supported \\
\hline Experience thrills/ excitement & 2.622 & 2 & .270 & Not Supported \\
\hline Have fun/ Maintain friendship & 26.005 & 2 & .000 & Supported \\
\hline Spend time with family & 25.911 & 2 & .000 & Supported \\
\hline Learn new things & 13.460 & 2 & .001 & Supported \\
\hline Develop my personal interests & 31.536 & 2 & .000 & Supported \\
\hline Gain a new perspective on life & 52.472 & 2 & .000 & Supported \\
\hline Have others know that I have been there & 10.488 & 2 & .005 & Supported \\
\hline $\begin{array}{l}\text { Experiencing different climate, landscape } \\
\text { and nature }\end{array}$ & 18.263 & 2 & .000 & Supported \\
\hline
\end{tabular}

Table 12 also provides statistics of Chi-square to test the second hypothesis of the study: there are different factors affecting the decision of visitors to go on domestic holidays. Using Chi-square test, it is found that 10 out of 13 factors significantly affecting visitors decisions of taking domestic tours, these factors are: safety $\left(X^{2}=6, D F=2\right.$, and $\left.P<0.05\right)$, health concerns $\left(\mathrm{X}^{2}=19.5, \mathrm{DF}=2\right.$, and $\left.\mathrm{P}<0.01\right)$, political stability $\left(\mathrm{X}^{2}=22.1, \mathrm{DF}=2\right.$, and $\left.\mathrm{P}<0.01\right)$, shortage of money $\left(X^{2}=16.8, D F=2\right.$, and $\left.P<0.01\right)$, lack of time $\left(X^{2}=12.5, D F=2\right.$, and $\left.P<0.01\right)$, destination $\left(X^{2}=35.1, D F=2\right.$, and $\left.P<0.01\right)$, value for money $\left(\mathrm{X}^{2}=7.6, \mathrm{DF}=2\right.$, and $\left.\mathrm{P}<0.05\right)$, weather $\left(\mathrm{X}^{2}=7.8, \mathrm{DF}=2\right.$, and $\left.\mathrm{P}<0.05\right)$, loss of property $\left(\mathrm{X}^{2}=7.4, \mathrm{DF}=2\right.$, and $\mathrm{P}<0.05)$, and accommodation $\left(\mathrm{X}^{2}=13.1, \mathrm{DF}=2\right.$, and $\left.\mathrm{P}<0.05\right)$. However, 3 factors were found not significantly affecting the decision of taking domestic tours. These factors are: travel fatigue $\left(\mathrm{X}^{2}=3.9, \mathrm{DF}=2\right.$, and $\left.\mathrm{P}>0.05\right)$, cultural risk $\left(\mathrm{X}^{2}=5.2, \mathrm{DF}=2\right.$, and $\left.\mathrm{P}>0.05\right)$, and other tourists $\left(\mathrm{X}^{2}=5.6, \mathrm{DF}=2\right.$, and $\left.\mathrm{P}>0.05\right)$. Therefore, it can be concluded that again the second hypothesis is supported.

Table (12) Chi-square statistics of factors affecting the decision to take domestic tours

\begin{tabular}{|l|l|l|l|l|}
\hline Factors & Chi-Square & DF & Sig. & Result \\
\hline Safety & 6.034 & 2 & .049 & Supported \\
\hline Health & 19.491 & 2 & .000 & Supported \\
\hline Political stability & 22.051 & 2 & .000 & Supported \\
\hline Shortage of Money & 16.719 & 2 & .000 & Supported \\
\hline Lack of time & 12.485 & 2 & .002 & Supported \\
\hline Destination & 35.149 & 2 & .000 & Supported \\
\hline Value for Money & 7.599 & 2 & .022 & Supported \\
\hline Travel fatigue & 3.952 & 2 & .139 & Not Supported \\
\hline Cultural risk & 5.171 & 2 & .075 & Not Supported \\
\hline Weather & 7.770 & 2 & .021 & Supported \\
\hline Loss of property (eg, theft, loss of luggage) & 7.394 & 2 & .025 & Supported \\
\hline Accommodation & 13.108 & 2 & .001 & Supported \\
\hline Other tourists & 5.562 & 2 & .062 & Not Supported \\
\hline
\end{tabular}




\section{H3: visitor travel-related characteristics is significantly affecting the decision of visitors to go on domestic holidays}

Testing the third hypothesis of the study: the activities contributing to enjoyment of holidays and taking domestic holidays, and using Chi-square test, it is found that 9 out of 18 activities significantly affecting visitors taking domestic tours as shown in Table 13, these activities are: shopping $\left(X^{2}=23, D F=2\right.$, and $\left.P<0.01\right)$, sightseeing in cities $\left(X^{2}=15.3\right.$, $\mathrm{DF}=2$, and $\mathrm{P}<0.01)$, swimming/ sunbathing $\left(\mathrm{X}^{2}=37.3, \mathrm{DF}=2\right.$, and $\left.\mathrm{P}<0.01\right)$, amusement/ theme parks $\left(\mathrm{X}^{2}=13.1, \mathrm{DF}=2\right.$, and $\mathrm{P}<0.01)$, disco/ night clubs $\left(\mathrm{X}^{2}=12.6, \mathrm{DF}=2\right.$, and $\left.\mathrm{P}<0.01\right)$, visiting small towns \& villages $\left(\mathrm{X}^{2}=7.9, \mathrm{DF}=2\right.$, and $\mathrm{P}<0.05)$, coastal location $\left(\mathrm{X}^{2}=22, \mathrm{DF}=2\right.$, and $\left.\mathrm{P}<0.01\right)$, museum/ gallery $\left(\mathrm{X}^{2}=6.1, \mathrm{DF}=2\right.$, and $\left.\mathrm{P}<0.05\right)$, and enjoying scenery $\left(X^{2}=21.9, D F=2\right.$, and $\left.P<0.01\right)$. However, 9 activities were found not significantly affecting the decision of taking domestic tours. These activities are: dining at cafe or restaurants $\left(\mathrm{X}^{2}=1.5, \mathrm{DF}=2\right.$, and $\left.\mathrm{P}>0.05\right)$, water sports $\left(\mathrm{X}^{2}=1.2, \mathrm{DF}=2\right.$, and $\left.\mathrm{P}>0.05\right)$, visiting heritage/ historical sites $\left(\mathrm{X}^{2}=4.5, \mathrm{DF}=2\right.$, and $\left.\mathrm{P}>0.05\right)$, environmental/ ecological excursions $\left(\mathrm{X}^{2}=1, \mathrm{DF}=2\right.$, and $\left.\mathrm{P}>0.05\right)$, eating seafood $\left(\mathrm{X}^{2}=4.3, \mathrm{DF}=2\right.$, and $\left.\mathrm{P}>0.05\right)$, going fishing $\left(\mathrm{X}^{2}=2.1, \mathrm{DF}=2\right.$, and $\mathrm{P}>0.05)$, snorkeling \& scuba diving $\left(\mathrm{X}^{2}=0.5, \mathrm{DF}=2\right.$, and $\left.\mathrm{P}>0.05\right)$, a warm, sunny climate $\left(\mathrm{X}^{2}=0.8, \mathrm{DF}=2\right.$, and $\left.\mathrm{P}>0.05\right)$, and meeting people $\left(\mathrm{X}^{2}=1, \mathrm{DF}=2\right.$, and $\left.\mathrm{P}>0.05\right)$. Therefore, it can be concluded that the third hypothesis is partially supported.

Table (13) Chi-square statistics of activities contributing to enjoyment level and taking domestic tours

\begin{tabular}{|l|c|c|l|l|}
\hline Activities & Chi-Square & DF & Sig. & Result \\
\hline Shopping & 23.033 & 2 & .000 & Supported \\
\hline Sightseeing in cities & 15.296 & 2 & .000 & Supported \\
\hline Dine at cafe or restaurants & 1.438 & 2 & .487 & Not Supported \\
\hline Swimming/ Sunbathing & 37.310 & 2 & .000 & Supported \\
\hline Amusement/ Theme Parks & 13.062 & 2 & .001 & Supported \\
\hline Water Sports (diving \&rafting) & 1.184 & 2 & .553 & Not Supported \\
\hline Visiting heritage/ historical sites & 4.535 & 2 & .104 & Not Supported \\
\hline Disco/ Night clubs & 12.621 & 2 & .002 & Supported \\
\hline Environmental/Ecological excursions & 1.033 & 2 & .597 & Not Supported \\
\hline Visiting small towns \& villages & 7.906 & 2 & .019 & Supported \\
\hline Eat seafood & 4.246 & 2 & .120 & Not Supported \\
\hline Go Fishing & 2.111 & 2 & .348 & Not Supported \\
\hline Snorkelling \& Scuba diving & .498 & 2 & .779 & Not Supported \\
\hline A warm, sunny climate & .839 & 2 & .657 & Not Supported \\
\hline Coastal location & 22.043 & 2 & .000 & Supported \\
\hline Meet people & 1.012 & 2 & .603 & Not Supported \\
\hline Museum/ Gallery & 6.119 & 2 & .047 & Supported \\
\hline Enjoy Scenery & 21.862 & 2 & .000 & Supported \\
\hline
\end{tabular}

\section{Conclusion and Recommendations}

This study aimed at to better understanding travel motivation, constraints and decision making in the context of Egypt pleasure travelers to domestic tours. Data were collected from 353 visitors at Sharm-Elsheik, Hurghada, Alexandria and North cost during summer 2014. It is found that, in the survey sample, 50.4\% of respondents are female, 58.5\% of respondents aged between 18 to 29 years, $68.4 \%$ are studying at college level. Most respondents are single (51.9\%) and $85.7 \%$ of respondents have household income below 25000 L.E. It is found that 2 out of 4 attributes are significantly affecting visitors decisions of taking domestic tours, these factors are: age and gender. However, 2 attributes were found not significantly education level and marital status. It is also revealed that 9 out of 10 motives affect visitor decisions to go on domestic tours, these motives are: escape from daily life/routine/pressure, rest and relax, having fun/ maintaining friendship, spending time with family, learning new things, developing personal interests, gaining a new perspective on life, having others know that I have been there, and experiencing different climate, landscape and nature while experiencing thrills/ excitement found not significant. The survey revealed that 10 out of 13 constraints significantly affecting visitors decisions of taking domestic tours, these factors are: safety, health concerns, political stability, shortage of money, lack of time, destination, value for money, weather, loss of property, and accommodation. However, 3 factors were found not significantly, travel fatigue, cultural risk and other tourists. Respondents mentioned that word of mouth is the first source of information (75.5\%) when they start their travel planning process.

Characteristics of Egyptians Travellers: Tourism is a seasonal activity, occurring mainly during holiday periods as well as weekends. As for taking domestic holidays as a family group within the last year, $51 \%$ went on one holiday. A percentage of $36.7 \%$ of respondents stays a week on holiday. Hotels or motels were the most preferred accommodation type of respondents $(48.1 \%), 24.2 \%$ of respondents' preferred rented house/ flat, $19.1 \%$ of respondents have their own holiday home. $77 \%$ of respondents use car on holiday while, $28 \%$ of respondents prefer air as the second means of travel to destination. It is found that 9 out of 18 activities significantly affecting visitors taking domestic tours, these activities are: shopping, sightseeing in cities, swimming/ sunbathing, amusement/ theme parks, disco/ night clubs, 
visiting small towns \& villages, coastal location, museum/ gallery, and enjoying scenery. However, 9 activities were found not significantly: dining at cafe or restaurants, water sports, visiting heritage/ historical sites, environmental/ ecological excursions, eating seafood, going fishing, snorkeling \& scuba diving, a warm, sunny climate, and meeting people. It is found that $50.4 \%$ of respondents travel with friends or with relatives, $43.6 \%$ of them travel with spouse and children, respondents claimed that booking direct with holiday providers comes first (59.1\% of respondents), next is booking via travel agents $(27.5 \%)$. Asking respondents about the budget they could reduce when planning their holidays, $49 \%$ of respondents said they can reduce the budget of cultural visits, $36.1 \%$ of respondents could reduce the budget of transportation. Food followed by accommodation and leisure activities are the most important items in their travel budget that Egyptians could not reduce. As a matter of fact, majority of Egyptians are still unable to pay for leisure visits to tourist destinations since nearly $40 \%$ of Egypt population below the poverty line. Under such circumstance, the special packages for residents such as relatively cheap hotel accommodation which are encouraged during low seasons when hotel occupancies are low will never be a panacea even though they should remain as motivation to the minority who can afford. On the other hand, even those in position to afford the packages still perceive the rates high for domestic tours.

Apparently, both government and tour operators' efforts have been biased towards supporting/encouraging international tourism. To this end, efforts by all stakeholders to boost domestic tourism and the overall tourism industry should go hand in hand with national strategy towards expanding domestic so long daily income is a bottleneck. However, the study illustrates some recommendations for encouraging domestic tourism:

1- long-term plans and strategies must be considered to make the domestic tourism compete with international tourism.

2- Diversification of tourism products is critically important so as to suit various categories of domestic visitors by political/economic status and income, age and sex, and encourage year round travel.

3-Create special activities for less visited areas and low season.

4-Enhance and implement levels of domestic tourism marketing.

5-Researches should be focus on areas where there is high potential for domestic tourism growth.

6- Urgent need of an affordable, safe and convenient access and transport modes to tourism destinations and products.

7- Use of combination of approaches towards improving domestic tourism of since various constraints of varying weights have been reported to affect domestic tourism.

\section{Limitations and Suggestions for Future Research}

First, the study was conducted in the summer, and thus findings were limited to summer travelers. Tourists who travel in different seasons may form different opinions of a destination. Future study would be implemented to examine the satisfaction of domestic tourists. Comparisons can also be made between the two markets (international and domestic) for the development through tourism policy. Additionally, the population of the study was also limited to visitors of a sun and sea tourist destination. Therefore, the results from the study may not be generalized beyond this population. Replicating similar studies in other tourist destinations would be imperative for increasing the generalizability of these findings. Finally, while this study focused on leisure travel of four days or longer, it is important to recognize that shorter duration leisure trips have very different characteristics and need to be studied as well.

\section{References}

1) Ajzen, I., (1991), "The Theory of Planned Behavior", Organizational Behavior and Human Decision Processes, 50, 179-211.

2) Baloglu, S. \& Uysal, M., (1996), "Market segments of push and pull motivations: a canonical correlation approach", International Journal of Contemporary Hospitality Management, 8 (3), 32-38.

3) Baloglu, S. and McCleary, K. W.,(1999), "A Model of Destination Image Formation", Annals of Tourism Research, Vol. 26, No. 4, pp. 868-897.

4) Bargeman, B. and H. van der Poel., (2006), "The role of routines in the vacation decision-making process of Dutch vacationers", Tourism Management, Vol. 27, pp. 707-720.

5) Beatty, S., and Smith, S., (1987), "External Search Effort: An Investigation Across Several Product Categories", Journal of Consumer Research, 14:83-95 in Gursoy, D., and McCleary, K.W., (2004), "An integrative model of tourists information search behavior", Annals of Tourism Research, Vol. 31, No. 2, pp. 353-373.Beerli, A. and Martin, J. D., (2004),"Tourists' characteristics and the perceived image of tourist destinations: a quantitative analysis- a case study of Lanzarote, Spain", Tourism Management, Vol. 25, pp. 623-636.

6) Beerli, A., G. Diaz Meneses, and S. Moreno Gil, (2007), "Self-Congruity and Destination Choice", Annals of Tourism Research, Vol. 34, No. 3, pp. 571-587. 
7) Bowen, D., \& Clarke, J., (2009), Contemporary tourist behaviour: Yourself and others as tourists. London, UK: Oxford Brookes.

8) Castano, B. J. M., Moreno, S. A., \& Crego, D. A., (2007), "Tourist profiles in a sample of Spanish subjects: An empirical segmentation model in relation to travel patterns and characteristics of the traveler", Estudios Turisticos, 17(1), 57-76.

9) Chun, M. K. (2009), "The managerial implications of an analysis of tourist profiles and international hotel employee service attitude", International Journal of Hospitality Management, 28, 302-309.

10) Cohen E., (1972), "Toward a sociology of international tourism", Social Research, 39(1), pg.164-89 in Oroian, M., Ratiu, R.F., \& Gheres, M., (2013) "Using the residents' profile as potential tourists in tourist market segmentation: the case of mures county, Romania" Academica Science Journal, Economica Series, No. 1 (2).

11) Crawfor, D. W., \& Godbey, G., (1987), "Reconceptualising barriers to family leisure", Leisure Sciences, 9, 119-127.

12) Crawford, D. W., E. L. Jackson, and G. Godbey, (1991), "A Hierarchical Model of Leisure Constraints", Leisure Sciences, 13, 309-20.

13) Crompton, J. L., \& Ankomah, P. K., (1993), "Choice set propositions in destination decisions", Annals of Tourism Research, 20(3), 461-476.

14) Crompton, J. L., (1979), "Motivations for pleasure vacation", Annals of Tourism Research, 6 (4), $408-424$.

15) Crompton, J. L. \& McKay, S, (1997), "Motives of visitors attending festival events", Annals of Tourism Research, 24 (2), 425-439.

16) Dann, G. M. (1981), "Tourism Motivations: An appraisal", Annals of Tourism Research, 8(2), $189-219$ in Mlozi, S., Pesämaa, O. \& Haahti, A., (2013), "Testing a model of destination attachment", Tourism and Hospitality Management, Vol. 19, No. 2, pp. 165-181.

17) Engel, J., Blackwell, R., and Miniard, P.,(1995), Consumer Behavior, (8th ed.) Fort Worth TX: Dryden in Gursoy, D., and McCleary, K.W., (2004), "An integrative model of tourists information search behavior", Annals of Tourism Research, Vol. 31, No. 2, pp. 353-373.

18) Eugenio-Martin, J. L., (2008), "Modelling Determinants of Tourism Demand as a Stage Process: A Discrete Choice Methodological Approach", Universidad de Las Palmas de Gran Canaria, Departamento de Analisis Economico Aplicado. Technical Paper.

19) Fesenmaier, D. R., \& Jeng, J. M., (2000), "Assessing structure in the pleasure trip planning process", Tourism Analysis, 5(1), 13-27.

20) Fodness, D., and Murray, B.,(1997), "Tourist Information Search", Annals of Tourism Research, 24:503-523.

21) Fodness, D., and Murray, B.,(1998), "A Typology of Tourist Information Search Strategies", Journal of Travel Research, 37:108-119.

22) Franch, M., Martini, U., Inverardi, P. L. N., \& Bufa, F., (2006), "From reconstruction and analysis of tourist profiles to some suggestions to destination management - an empirical research in the dolomites area", Tourism Review, 61(2), 30-37.

23) Gartner,W.C.,(1993), "Image formation process", Journal of Travel and Tourism Marketing, 2,191-215

24) Goossens, C., (2000), "Tourism information and pleasure motivation", Annals of Tourism Research, 2, 301321.

25) Gursoy, D., and Chen, J., (2000), "Competitive Analysis of Cross Cultural Information Search Behavior", Tourism Management , 21:583-590.

26) Huh, J., Uysal, M., \& McCleary, K., (2006), "Cultural/heritage destinations: Tourist satisfaction and market segmentation", Journal of Hospitality and Leisure Marketing, 14(3), 81-99.

27) Jackson, E. L., (1988), "Leisure constraints: A survey of past research", Leisure Sciences, 10, $203-215$.

28) Jang, S. \& Wu, C. (2006), "Seniors' travel motivation and the influential factors: An examination of Taiwanese seniors", Tourism Management, 27, 306-316.

29) Jenkins, R. L. (1978), "Family vacation decision-making", Journal of Travel Research,18 (2), 2-7 in Zhang, W., ( 2009), " The Motivations, Constraints and Decision-making of Beijing Outbound Tourists", A thesis submitted for a PHD degree, University of Waikato, Hamilton, New Zealand.

30) Johnson, P. and J. Ashworth, (1990), "Modeling Tourism Demand: A Summary Review", Leisure Studies, Vol. 9, pp. 145-160.

31) Kattiyapornpong,U., and Miller, K.E., (2007), "Differences within and between travel preference, planned travel and choice behavior of Australians traveling to Asian and overseas destinations", A paper presented in The Council for Australasian University Tourism and Hospitality Education (CAUTHE) Conference, Tourism: Past Achievements, Future Challenges, Australia.

32) Keegan, Warren J, Green, Mark C. 2008. Global Marketing, 5th edition. Pearson Prentice Hall, USA in Koppalova, N., (2014)," German Market Analysis: Tourist Behaviour Research. Case: Rock and Lake", A thesis submitted for a Master degree, Mikkeli University of Applied Sciences, Finland.

33) Kotler, P. (1997), Marketing Management (9th ed.). New Jersey: Prentice Hall in Liu, H., (2014), "Understanding Destination Choice from a Cultural Distance Perspective", A thesis submitted for a Master degree, University of South Carolina - Columbia. 
34) Kotler, P., Bowen, J. and Makens, J., (2006), "Marketing for hospitality and tourism", 4th Ed, Upper Saddle River, Pearson Prentice Hall.

35) Kozak, M., Bigne, E., \& Andreu, L. (2004), "Satisfaction and destination loyalty: A comparison between nonrepeat and repeat tourists", Journal of Quality Assurance in Hospitality and Tourism, 5(1), 43-59.

36) Lam, T. \& Hsu, C. H. C., (2006), "Predicting behavioral intention of choosing a travel

37) Destination", Tourism Management, 27, 589-599.

38) Lang, C., O'Leary, J.T., \& Morrison, A.M., (1997), "Distinguishing the destination choices of pleasure travelers from Taiwan", Journal of Travel \& Tourism Marketing, 6 (1), 21-40.

39) Lehto, X. Y., J. T. O'Leary and A. M. Morrison, (2004), "The Effect of Prior Experience on Vacation Behavior", Annals of Tourism Research, Vol. 31, No. 4, pp. 801-818.

40) Liu, H., (2014), "Understanding Destination Choice from a Cultural Distance Perspective", A thesis submitted for a Master degree, University of South Carolina - Columbia.

41) Lomine, L. and Edmunds, J., (2007), Key concepts in tourism, New York: Palgrave Macmillan.

42) Maser, B. and Weiermair, K., (1998), "Travel decision making: from the vantage point of perceived risk and information preferences", Journal of Travel and Tourism Marketing, (7): 107-21.

43) Massidda, C., \& Etzo, I., (2012), "The determinants of Italian domestic tourism: A panel data analysis", Tourism Management, 33(3), pg. 603-610.

44) McGehee, N., Loker-Murphy, L., \& Uysal, M., (1996), "The Australian international pleasure travel market: Motivations from a gendered perspective", Journal of Tourism Studies, 7 (1), 45-57.

45) McKercher, B., \& Wong, D. Y. Y, (2004), "Understanding tourism behavior: Examining the combined effects of prior visitation history and destination status", Journal of travel Research, 43(2), 171-179.

46) Mergoupis, T., \& Steuer, M., (2003), "Holiday taking and income" Applied Economics, 35, 26984.Mieczkowski, Z., (1990), "World trends in tourism and recreation", en Amercian University Studies Series XXV Georgraphy, 3, New York: Peter Lang.

47) Moutinho, L. (1987), "Consumer behavior in tourism. European", Journal of Marketing,21(10), 3-44 in Zhang, W., ( 2009), " The Motivations, Constraints and Decision-making of Beijing Outbound Tourists", A thesis submitted for a PHD degree, University of Waikato, Hamilton, New Zealand.

48) Murphy, L., Mascardo, G., Benckendorff, P.,(2007), "Exploring word-of-mouth influences on travel decisions: friends and relatives vs. other travelers", International Journal of Consumer studies, 31, (5): 517-527.

49) Nicolau, J. L. and F. J. Mas, (2005), "Stochastic Modeling: A Three-Stage Tourist Choice Process", Annals of Tourism Research, Vol. 32, No. 1, pp. 49-69.

50) Oh, H. C., Uysal, M., \& Weaver, P. A., (1995), "Product bundles and market segments based on travel motivations: A canonical correlation approach", International Journal of Hospitality Management, 14(2), 123 137.

51) Oroian, M., Ratiu, R.F., \& Gheres, M., (2013) "Using the residents' profile as potential tourists in tourist market segmentation: the case of mures county, Romania" Academica Science Journal, Economica Series, No. $1(2)$.

52) Page,S. J., (2009), Tourism management: managing for change 3rd edition. United States of

53) America: Butterworth-Heinemann.

54) Page, S. J. and Connell, J., (2006), Tourism: a modern synthesis 2nd edition. London:

55) Thomson.

56) Papatheodorou, A., (2001), "Why People Travel to Different Places", Annals of Tourism Research, Vol. 28, No. 1, pp. 164-179.

57) Pearce, P., (2005), "Tourist Behavior - Themes and Conceptual Schemes", Clevedon, UK: Channel View Publications.

58) Plog S., (1974), "Why destination areas rise and fall in popularity", The Cornell Hotel and Restaurant, Administration Quarterly, 14(4), pg. 55-58 in Oroian, M., Ratiu, R.F., \& Gheres, M., (2013) "Using the residents' profile as potential tourists in tourist market segmentation: the case of mures county, Romania" Academica Science Journal, Economica Series, No. 1 (2).

59) Pyo, S., Mihalik, B. J., \& Uysal, M., (1989), "Attraction attributes and motivations: A canonical correlation analysis", Annals of Tourism Research, 16, 277-282.

60) Romsa, G., \& Blenman, M., (1989), "Visitor patterns of elderly Germans" Annals of Tourism Research, 16, 178-188.

61) Samdahl, D.M., \& Jekubovich, N.J., (1997),"A critique of leisure constraints: Comparative analyses and understandings", Journal of Leisure Research, 29 (4), 430-452.

62) Schiffman, L. G., \& Kanuk, L. L. (1997), Consumer Behavior. New Jersey: Prentice Hall in Liu.H., (2014), "Understanding Destination Choice from a Cultural Distance Perspective", A thesis submitted for a Master degree, University of South Carolina - Columbia.

63) Schul, P., and Crompton, J., (1983), "Search Behavior of International Vacationers: Travel-Specific Lifestyle and Socio-demographic Variables", Journal of Travel Research, 22(3):25-31.

64) Snepenger, D., \& Snepenger, M., (1993). "Information search by pleasure travelers", In M. A. Kahn, M. D. Olsen, \& T. Var, Encyclopedia of hospitality and tourism (pp. 830-835). New York: Van Nostrand Reinhold. 
65) Snepenger, D., Meged, K., Snelling, M. and Worrall, K., (1990), "Information Search Strategies by Destination -Na1ve Tourists", Journal Travel Research, 29(1):13-16.

66) Solomon, M. R. (1996), Consumer behavior: Buying, having, and being. New Jersey: Prentice Hall in Liu, H., (2014), "Understanding Destination Choice from a Cultural Distance Perspective", A thesis submitted for a Master degree, University of South Carolina - Columbia.

67) Sparks, B. A., (2007), "Planning a wine tourism vacation? Factors that help to predict tourist behavioural intentions, Tourism Management, 28, 1180-1192.

68) Swarbrooke, J., \& Horner, S. (2007), Consumer Behaviour in Tourism (2nd ed.). London: ButterworthHeinemann.

69) Tay, R., McCarthy, P. S., \& Fletcher, J. J. (1996), "A portfolio choice model of the demand for recreation trips", Transportation Research B, 30(5), 325-337.

70) Um, S., \& Crompton, J. L. (1990), Attitude determinants in tourism destination choice, Annals of Tourism Research, 17(3), 432-448.

71) Uysal, M., McDonald, C. D., \& Reid, L. J., (1990), "Sources of information used by international visitors to US parks and natural areas", Journal of Park and Recreation Administration, 8(1), 51$\} 59$.

72) Vogt, C., and Fesenmaier, D., (1998), "Expanding the Functional Information Search", Annals of Tourism Research, 25:551-578.

73) Weaver, D. and Lawton, L., (2002), Tourism management 2nd edition. Australia: John Wiley and Sons.

74) Woodside, A. G., \& Lysonski, S. (1989), "A general model of traveler destination choice", Journal of Travel Research, 27(4), 8-14.

75) Wu, C.L., \& Carson, D., (2008), "Spatial and temporal tourist dispersal analysis in multiple destination travel", Journal of Travel Research,46(3), 311-317.

76) Yoon, Y. \& Uysal, M. (2005), "An examination of the effects of motivation and satisfaction on destination loyalty: A structural model", Tourism Management, 26, 45-56.

77) Zhang, W., ( 2009), " The Motivations, Constraints and Decision-making of Beijing Outbound Tourists", A thesis submitted for a PHD degree, University of Waikato, Hamilton, New Zealand.

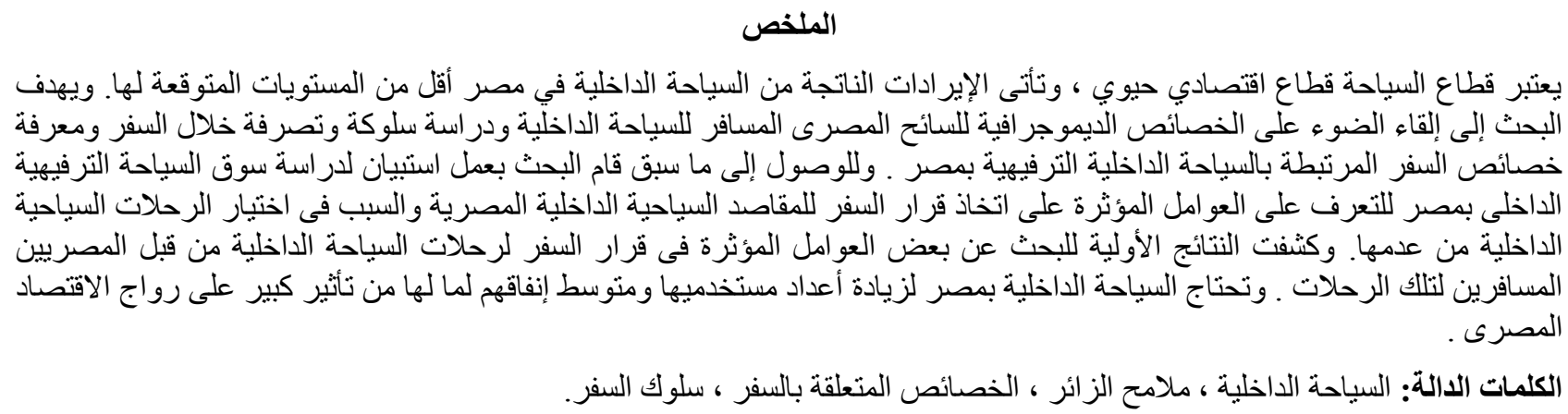

